\title{
The Role of Metalanguage in Supporting Academic Language Development
}

\author{
Mary J. Schleppegrell \\ University of Michigan
}

Recent currents in language learning research highlight the social and emergent aspects of second language (L2) development and recognize that learners need opportunities for interaction in meaningful contexts supported by explicit attention to language itself. These perspectives suggest new ways of conceptualizing the challenges faced by children learning L2s as they learn school subjects. This article reports on design-based research in U.S. schools with a majority of English language learners, where teachers were supported in using Systemic Functional Linguistics metalanguage in the context of curricular activities. This work illustrates how a meaningful metalanguage can support L2 learners in accomplishing challenging tasks in the primary school curriculum at the same time that it promotes the kind of focused consciousness-raising and explicit talk about language that has been shown to facilitate L2 development. Examples from classroom research exemplify how metalanguage supports the situated and contextual language learning that current research in education and L2 acquisition calls for, while also supporting disciplinary goals and activities in English language arts.

Keywords English language learners; grammar; elementary school; systemic functional linguistics; English language arts

\section{Introduction}

Growth in immigrant populations in schools around the world raises new challenges for researchers interested in instructed second language (L2)

\footnotetext{
I am grateful to Annemarie Palincsar, Jason Moore, and other members of the Language and Meaning project for their contributions to this work. I also thank the teachers and children in our project. The editors and reviewers for Language Learning made valuable suggestions for improvement for which I am appreciative. The research reported here was supported by the Institute of Education Sciences, U.S. Department of Education, through Grant R305A100482 to the University of Michigan. The opinions expressed are my own and do not represent views of the Institute or the U.S. Department of Education.

Correspondence concerning this article should be addressed to Mary J. Schleppegrell, School of Education, 610 East University Avenue, University of Michigan, Ann Arbor, MI 48109. E-mail: mjschlep@umich.edu
} 
development. L2 learning in schooling contexts needs to be conceptualized in ways that recognize the challenges and opportunities of learning a new language in the context of subject-matter learning. Different from the mostfrequently studied groups in second language acquisition (SLA) research (e.g., university foreign language learners), school children often quickly develop informal registers of the new language that serve them well in interaction with peers and teachers about everyday things. On the other hand, many of these children have few opportunities outside of school to learn or use the academic language needed for success in school contexts (Schleppegrell, 2012). They are often provided specialized support for L2 learning only in their first months in the new language context, and so exhibit an achievement gap in comparison with their native speaker peers, as the specialized registers of different disciplines and the more formal ways of presenting knowledge that are valued in the context of schooling are learned on much longer trajectories (Christie, 2012; Christie \& Derewianka, 2008).

Several currents in recent research converge in offering key principles for addressing this challenge. These currents have in common their recognition that L2 learning is always situated in particular contexts of language use where the context shapes the language learned, that language learning is a process of developing new resources for meaning-making, and that language learners need opportunities for participation in meaningful activities and interaction supported by consciousness-raising and explicit attention to language itself in all its complexity and variability.

Recognition of the role of purposeful interaction and participation in meaningful activities to support language development has a long history in SLA research and has recently been connected with other theoretical perspectives grounded in social views of language (e.g., Gibbons, 2006; Watson-Gegeo \& Nielsen, 2003; Young, 2008; Zuengler \& Miller, 2006). Zuengler and Miller (2006) describe how sociocultural perspectives have come to prominence in SLA research. Young (2008) characterizes these perspectives as understanding language learning "to include not only acquisition of knowledge about language but also development of ways in which language and other semiotic systems are put to use in the service of socialization to a new culture and participation in a new community" (p. 159). Language is learned through engagement in activities that enable participants to use the language resources they have in interaction, which in turn allows them to come to know and use new language resources. This suggests that students need opportunities to participate in interaction in the context of meaningful academic activities that enable them to meet the demands of schooling in every subject across the school years. 
A second major current in language learning research, the emergentist proposal (Ellis \& Larsen-Freeman, 2006), also supports a focus on meaning in context and adds the perspective that conscious attention to language itself facilitates L2 development. Ellis and Larsen-Freeman (2006) define language as "a multi-agent, complex, dynamic, adaptive system" (p. 558). Language development involves changes in learners' emerging linguistic systems as they adapt in response to new experiences and feedback. L2 development is both social and cognitive, as cognition itself is socioculturally situated. The emergentist perspective points out that many complex systems operate in any instructional context, including learners at varied proficiency levels, language systems of different kinds (i.e., the learners' first and second languages), and both language and content goals. Learning through instruction needs to be supported by "the social recruitment of the dynamics of learner consciousness, attention, and explicit learning," with opportunities for focus on language itself to achieve development to advanced levels (Ellis \& Larsen-Freeman, 2006, p. 568).

Another important current in language learning research is the use of the theory of Systemic Functional Linguistics (SFL) to describe and support language development (e.g., Byrnes, 2009; Christie, 2012; Schleppegrell, 2004). SFL, the linguistic theory developed by Michael Halliday (e.g., Halliday, 1978; Halliday \& Matthiessen, 2004), describes language as a social semiotic and offers a functional grammar that connects language forms with meaning in contexts of use. SFL and emergentist theories have common concerns in pointing to the dialectical relationships inherent in processes of language learning (Matthiessen, 2009). Halliday (1993), for example, noted that language learners use language systems to build meanings, but through their language use they also come to understand the potential of the systems. A key aspect of this perspective is that interaction in the context of shared experience enables learners to come to know the linguistic systems and develop their potential to participate. Halliday pointed out that language learning is always simultaneously learning in other domains as well, as learning a new language also entails learning to use that language in new meaning-making contexts. Different areas of meaning potential are associated with different social contexts, as the context makes different semantic systems differentially available (Halliday, 2007/1978). This means that language proficiency is register specific, related to the different opportunities learners have to use language for different purposes. Instruction can help learners recognize that what they "mean" comes out of the lexicogrammatical choices they make in contexts of use (Hasan \& Perrett, 1994). 
In common across these currents in language learning research is the view that L2 development emerges in social interaction in contexts of authentic engagement in meaning-making, and that language development can be supported through explicit focus on language itself that raises students' consciousness about form-meaning relationships. This article reports on an approach to research that is using the metalanguage of SFL to support activities in the elementary school classroom that stimulate the noticing, consciousness-raising, and focused attention known to support L2 learning, while at the same time enabling disciplinary learning that supports the interpretation and analysis valued in English language arts (ELA). The activities support teachers and learners in linking language and content in an interactive pedagogy that gives learners opportunities for an explicit focus on language as they are learning across the school years.

\section{Metalanguage in the Service of Learning Language and Learning Through Language}

Being explicit about language requires metalanguage (language about language), but use of metalanguage does not in itself support connections to meaning that connect with disciplinary goals in teaching. In SLA research, explicit instruction is typically described in terms of focus on form and the discussion of rules, and contrasted with implicit instruction, where rules are not evoked or discussed (see Andringa, de Glopper, \& Hacquebord, 2011.) Meta-analyses of focus on form and explicit focus on rules in language teaching (e.g., Spada \& Tomita, 2010) have shown that such focus can be effective in promoting more accurate use of the L2 (e.g., Simard \& Jean, 2011). But in the context of education and writing instruction, studies show that just learning linguistic terminology is not supportive of other learning goals in and of itself (Myhill, 2003; Svalberg, 2007).

Berry (2010) points out that metalanguage can be conceived of as both thing (terminology) and process (talk about language), and in the research reported here, the focus is not on teaching metalanguage terminology, but on using meaning-focused metalanguage to help students participate in gradelevel tasks and make effective discursive choices. The project builds on earlier research using SFL, including foundational work in Australia (Martin, 1993) and SFL descriptions of language development across the years of schooling and across content areas (e.g., Christie, 2012). The project also draws on research demonstrating the value of SFL metalanguage in classrooms with first and second language learners (e.g., Brisk \& Zisselsberger, 2010; de Oliveira, 
2008; French, 2010; Gebhard, Harman, \& Seger, 2007; Quinn, 2004; Williams, 2004). In the United States, work with history teachers has shown the value of SFL metalanguage in highlighting key disciplinary meanings such as agency and interpretation (Schleppegrell, 2011).

\section{Design-Based Research: Metalanguage in Service of Curricular Goals}

This article draws on data from the first and second years of a 3-year designbased project to develop and study an intervention that uses SFL metalanguage to support the achievement of curricular goals in elementary ELA in classrooms with English language learners (ELLs). The project uses design-based research (Anderson \& Shattuck, 2012; Collins, Joseph, \& Bielaczyc, 2004) to develop an approach based on functional grammar to support the academic language development of ELLs in grades 2 to 5 in a diverse Arabic-language urban fringe community in the United States. The community resembles many communities around the world where L2 speakers are concentrated and where schools are challenged to support academic language development in the classroom. In such communities, the new language is learned in the context of subject-matter learning, where students have few opportunities outside the classroom to use academic language.

In design-based research, both the development of an intervention and its enactment are studied in order to explore and develop theories of learning and teaching. Edelson (2002, p. 106) characterized design research as "formative research in complex real world settings" that engages in iterative cycles of design and implementation, with data collected to inform subsequent design, and then reflection on the design and its outcomes to revise and develop a coherent theory. Practical and applicable lessons can be learned from designbased research, as it is directly engaged in the improvement of educational practice. To develop successful models, researchers need to document processes of enactment and triangulate from multiple data sources. As they do so, their theories of learning also evolve and re-inform subsequent iterations in the design process.

Context is crucial to design-based research, which does not focus on the development of a product, but instead on generating models of successful innovation that help us understand the nature of learning in a complex system. Elements of context that influenced the design decisions for this project include the instructional materials and participation structures already in place in the classrooms, the teachers' knowledge about language, the children's 
levels of proficiency in English, as well as institutional constraints imposed by district- or school-level policies. Design-based research involves multiple iterations of creating, piloting, refining, and then implementing and studying new innovations in authentic contexts of educational practice. Its main focus is the building of theory and development of design principles for both research and practice.

Initially a team of researchers worked closely with a small group of teachers, introducing them to SFL metalanguage in talk about the texts of their literacy curriculum. The teachers subsequently used the metalanguage in interaction with students, and learning from this observation of enactment, the researchers created units of study that were implemented by other teachers after professional development sessions that introduced the units and gave teachers opportunities to learn and practice using the approach. Observation of this enactment brought into focus the challenges and affordances of the metalanguage use across grade levels and contexts. Nineteen teachers in grades 2 to 5 have worked with the project over the two years as the approach has been refined and developed. Over time, this work has contributed to a more powerful situating of the metalanguage use in service of curricular goals.

For this article, data from classroom enactments were analyzed to identify moments when use of metalanguage stimulated the kinds of interaction that the research reviewed above suggests is supportive of L2 development, as well as being supportive of the goals of the literacy curriculum. Study of these events sheds light on the roles the metalanguage plays in producing noticing and consciousness raising about language-meaning connections.

Learning to use new metalanguage is a skill in itself that needs to be taught, but to be meaningful, the learning of metalanguage needs to be situated in instructional contexts where it resonates with and helps support content goals. The examples presented here show how teachers situated talk about language in the curricular context and used it to support their larger instructional goals. In each case, the teachers have learned about a language system and the options in the system that offer choices in meaning, and they are implementing activities that enable students to recognize and discuss the impact of those different choices. The examples show teachers and children linking forms and meanings in two language systems: grammatical mood mapped to speech function, and transitivity in the clause mapped to four domains of meaningdoing, saying, sensing, and being. The examples also illustrate how such a focus supports curricular goals. The use of metalanguage enables engagement in interaction that supports students in seeing patterns in language and abstracting from particular instances to the language systems from which the instances 
are drawn, and helps students recognize meaningful constituents and explore register variation.

\section{Talking About Mood and Speech Function: Learning About Register Variation}

The language system under discussion in the example presented below is an aspect of interpersonal meaning; the linking of grammatical mood with the speech functions that the moods construe in particular examples. The second grade teacher has been introduced to the SFL perspective on speech function, which identifies four possibilities: Offer, Statement, Question, and Command. The teacher's goals are to help children recognize that the different speech functions are accomplished through a variety of mood choices and to consider the effect of those choices on the listener in the context of reading the story Officer Buckle and Gloria by Peggy Rathmann, about a police officer who gives safety lectures at schools and thus provides many examples of commands such as "Keep your shoelaces tied" and "Never stand on a swivel chair." The teacher has created a chart that introduces the three grammatical moods (she calls them "voices") and the four speech functions (see Table 1 for a partial reproduction of this chart).

Table 1 displays how functions such as command can be realized in different grammatical moods. The teacher has assigned students sentences from the story, asking them to identify the mood (declarative, interrogative, or imperative) and speech function (offer, statement, question, or command) in the context of the story, and to place the sentence appropriately on the chart. Table 1 shows that many of the sentences are commands, realized through all three mood options. In conversation about their categorizations, at one point the teacher asks, "Hussein do you know a command, can you give me a command?" Hussein responds, "Well you just said one." This comment leads to lively discussion. The teacher asks, "Did I give you a command?" and the children shout out responses, some agreeing and some disagreeing. When the teacher asks, "What kind of command?" a student identifies what the teacher said as grammatically a question, glossed then by the teacher as interrogative. Students' recognition that the interrogative form "Can you give me a command?" functions as a command in this context leads the class into a conversation about different ways of giving commands, about who can command whom and in what ways, and about how some commands are "nicer" than others. This exchange echoes the ways discussion about indirect speech acts is typically part of an ESL curriculum, where it is often presented as a matter of politeness. Throughout 
Table $1 \mathrm{Mood} / \mathrm{speech}$ function chart (partial representation)

\begin{tabular}{|c|c|c|c|}
\hline $\begin{array}{l}\text { Mood/Speech } \\
\text { Function }\end{array}$ & Declarative & Interrogative & Imperative \\
\hline Offer & $\begin{array}{l}\text { "We'd like you to } \\
\text { come tell your } \\
\text { safety tips." }\end{array}$ & $\begin{array}{l}\text { "Would you like to } \\
\text { join me today?" }\end{array}$ & \\
\hline Statement & $\begin{array}{l}\text { "Officer Buckle, it's } \\
\text { time for our safety } \\
\text { speech." } \\
\text { "You and Gloria } \\
\text { make a good } \\
\text { team." }\end{array}$ & & \\
\hline Question & & "Where is Gloria?" & \\
\hline \multirow[t]{2}{*}{ Command } & $\begin{array}{l}\text { "I'd like someone to } \\
\text { close the door." }\end{array}$ & $\begin{array}{l}\text { "Can you give me a } \\
\text { command" }\end{array}$ & $\begin{array}{l}\text { "At least bring } \\
\text { along the police } \\
\text { car." }\end{array}$ \\
\hline & & $\begin{array}{l}\text { "Would you please } \\
\text { sit right" }\end{array}$ & $\begin{array}{l}\text { "Keep your } \\
\text { shoelaces tied." } \\
\text { "Always wipe up } \\
\text { spills before } \\
\text { someone slips } \\
\text { and falls." }\end{array}$ \\
\hline
\end{tabular}

the conversation, pragmatic issues of status and power are in focus as the children talk about the ways their parents and teachers give commands and the force of those commands.

The children are highly engaged over more than an hour of discussion about mood and speech function, and while often their labeling is mistaken in this first lesson with this new metalanguage, their contributions indicate their understanding of the issues in focus. This becomes clear toward the end of the lesson when a student asks, "Can I say a command?" The command she offers is "I'd like someone to close the door." Again, the teacher asks, "Is that even a command?" and again there is discussion about the pragmatic force of this declarative. Later in the lesson, following further practice with commands and questions, the same student again bids for the floor and makes this contribution: "When I said I'd like you to close that door you could say interrogative uh would you mind closing the door and imperative uh close that door." This second grade student has offered an example of the ways the same speech function can be 
realized in the three grammatical moods, demonstrating understanding that the various moods can all be recruited in the service of commanding:

declarative: I'd like you to close that door.

interrogative: Would you mind closing the door?

imperative: Close the door!

The curricular goal of the lesson is brought into focus by the teacher after the categorization, as she asks, "Now, what do you notice, what's going on here?" The children call out, "Pattern, pattern," and then Jenna volunteers, "There's a lot of different parts, a lot of voices." The teacher responds, "Right, we have different voices, but where do you see the most moods of voices concentrated?" Students observe and the teacher acknowledges that most sentences are in the declarative, statement category, and the teacher then asks, "Where else would you see a lot of, one mood voice concentrated, in what area?" Aya responds command, imperative, and the teacher makes a connection between the language forms and the register of the story: "Why is this imperative, a lot of commands? What was really that story about?" The children chorus "commands" and the teacher makes the point that the story is about safety tips presented in commands. The students themselves then write safety tips and identify the mood of each of their commands.

This discussion is supportive of second language development in several ways. First, the students are abstracting from particular examples to recognize the systems of language being instantiated, connecting form with function and recognizing that they can use different forms for the same function. They are also learning about register variation: that they can make choices about how to command, and that different choices are appropriate for different purposes. Finally, the metalanguage supports curricular learning, as students recognize how language choices contribute to the meaning of a literary text, an important goal of ELA.

\section{Talking About Process Types: Learning About Character Analysis}

Recognizing that "meaning is construed in networks of interrelated contrasts" (Halliday \& Matthiessen, 2004, p. 47) puts a focus on meaning first. Each instance of language use is multifunctional, so that, for example, instantiations of the word class verb can be analyzed for their contribution to interaction (through selection of mood, for example) at the same time they contribute to the construal of experience by mapping onto different semantic domains. The language system in focus in this second example is the system of transitivity, construing experience into a set of process types. The SFL grammar describes 
the clause as presenting processes of happening, doing, sensing, saying, being or having, unfolding through time with participants involved in the process and circumstances attendant on the process (Halliday \& Matthiessen, 2004, p. 170). This construct of SFL focuses on the ways human experience is construed in language, with the three central processes being the material, those goings-on in the world outside of ourselves, the mental, the inner experience of consciousness, and the relational, the generalization of experience that identifies and classifies. The functions and meanings presented in these different process types are realized in different grammatical patterns characteristic of clauses of these types. So, for example, material processes typically involve an actor and their default tense in English is present progressive (I'm going to school). Mental processes can project other clauses and the default tense is simple present ( $I$ think I'll stay home today). Relational processes are realized in verbs of being and having. For pedagogical purposes, this project adopted the four-way distinction among process types of Martin and Rose (2003), presenting to teachers and students the notion of processes of doing, saying, sensing, and being. Each clause can be categorized as one of these process types, with some boundary disputes in interpretation that stimulate rich discussion about meaning.

In an example from another second grade classroom, the teacher asks the children to identify the pig's doing processes in the story Julius, by Angela Johnson. Julius, the pig, does not act very well in the story, especially at the beginning, and the teacher's goal is to develop a contrast between what Julius does early in the story and what he does after he has learned some manners. The teacher asks the children to work in groups to highlight the doing processes of Julius, who is introduced in this way: "it was a pig. A big pig. An Alaskan pig, who did a polar bear imitation and climbed out of the crate." A group has highlighted "did a polar bear imitation" and the teacher stops to ask the class whether they were right to highlight that part. The students respond with differing opinions, some of them saying "no." The teacher asks, "Who's saying no and why do you think not?" A student responds, "cuz he wasn't a polar bear he was a pig." This leads the teacher and class into a discussion about the meaning of "imitate" and "imitation," and they discuss other kinds of imitating and share their own experiences of imitating. At the end the teacher asks again, "So do you think he did something here? or no?" and the students together say, "He did." The teacher concludes, "He did he tried ... to act like a polar bear so that was a doing process done by the pig ... I want you to highlight the sentence because that shows the process."

Seeking the doing of the character and talking about everything he does leads to opportunities for close attention to meaning as the students and teacher 
unpack complex sentences. This abstraction from the instance "did an imitation" to a category of meaning, doing, is a means of identifying where further discussion about the sentence would be helpful, and enables the teacher to recognize when something is not understood by everyone in the class. When the students suggest that those who highlighted "did a polar bear imitation" were mistaken in identifying that as something Julius did, the teacher is able to confirm that this is indeed something the pig did. Analysis of classroom interaction supported by the SFL metalanguage has revealed many instances where misunderstandings about word meaning surface in the context of the functional labeling.

Students in the early grades are capable of engaging in talk about distinctions in meaning in text, abstracting from the actual wording to the meaning categories represented by the process types. This reinforces their understanding and provides opportunities for teacher and children to engage in deeper discussion of text meaning. The discussion is not just a grammatical exercise of labeling parts of speech. Because the discussion is about connections to meaning, the talk about language enables conversation about what a character does, says, and thinks, as well as how characters are described by the author and how characters evolve across a text.

But the greater value of the metalanguage is in the ways it can also help language learners achieve important ELA curricular goals. One such goal is understanding character development in literary texts. Using the notion of processes of different types, the teacher can ask a question like "how does the author represent the character's feelings at this point in the story?" Answering such a question pushes the students to focus on patterning in the grammatical realizations of meaning about feeling. While in many cases feelings are realized in expected ways in sensing processes (he loved reading), the students need to recognize feeling, no matter in what kind of processes it is construed. To support this, children are first asked to identify feelings and then think about the types of processes the author uses to show those feelings. In the texts of the ELA curriculum, authors often use processes of doing to show feelings, rather than using processes of sensing or being to tell feelings. For example:

George's father was angry and disappointed. He stormed into the house looking for George.

The author uses being (he "was angry and disappointed") to tell the readers directly what George's father felt. On the other hand, the author also expresses feelings in the doing process "stormed into the house." As "show, don't tell" is 
a common principle for writing vivid literature, many important meanings are represented in metaphoric ways in the language of doing in the early reading curriculum. Having children think about how authors use processes of different kinds to express something about a character helps them recognize how showing is accomplished.

Teachers can then support children's writing by suggesting the process types that will be helpful as they interpret and evaluate a character. For example, doing can be turned into being or sensing (e.g., George's father took a deep breath and then called his son- $>$ George's father didn't want to talk to George when he was angry) and sensing processes can be used to offer evaluation of the character (e.g., "I think he's a good father because he stops to take a breath and calms down before calling George"). This models for students some valued choices they can make as they engage in writing different kinds of texts without giving them templates or specific wording. With sensitivity to the notion of processes of different types, children can engage in discussion about the language choices an author makes and then think about their own language choices. The meaning is considered in relation to the wording and both are related to the purpose and what is accomplished in the context of the curricular task. The metalanguage makes knowledge about language relevant for academic language development by enabling obscure tasks such as "interpretation" to be spelled out in terms of the linguistic resources needed to accomplish the tasks. Teachers report that this metalanguage of process types has been very productive in their discussions about characters and how they change and develop over a text. In addition, teachers report that talk about process types has also become a practice children engage in on their own, in other contexts, using this metalanguage to help them comprehend what they are reading and make choices as they write.

\section{The Value of Metalanguage for L2 Learning}

The SFL metalanguage is a meaning- or content-oriented metalanguage, providing a vocabulary for raising language awareness that can be linked to the purposes for which language is being used and the goals of the speaker/writer. Its meaning-exemplifying language provides a mode of inquiry for students, as it puts wording into categories of meaning, allowing students to abstract from specific instances to reflect on the properties of the systems of language. This enables students to explore the choices speakers and writers make, unpacking text to talk about meaning and recognizing patterns in language.

For example, using the metalanguage of mood/speech function, the teacher and students can talk about how strong a voice is when giving different kinds of 
commands, where different kinds of commands are heard, and why there are so many commands in the story they read. For academic language development, this is an important discussion, as one of the challenges for learners is being able to talk and write about what they are learning in different contexts and for different kinds of tasks. Using the metalanguage of processes of different kinds, learners can talk about how an author shows with doing processes and tells with sensing and being processes and what that contributes to more vivid writing. The metalanguage helps make explicit the demands of the ELA curriculum in meaningful ways.

Thinking in terms of the functional categories helps learners begin to see the larger systems in the language and the options they have for making choices from those systems in different contexts. At the same time that the children are developing new understandings about language, this work is also supporting educational practice by enabling abstraction and categorization. They can consider the question What is "I'd like you to close the door" an instance of? and use the metalanguage to identify it as both declarative and command and then explore other ways of commanding. In response to the question What is "did an impression" an instance of?, they learn to see it as an action in the world. The metalanguage also enables teachers to be explicit about what interpretation involves (e.g., turning doing into sensing/being).

The metalanguage of mood/speech function and processes of different kinds are two examples of new semiotic tools these learners are using to parse the elements of a clause into meaningful segments and explore the meaning of lexical and grammatical choices in the context of important curricular work. The metalanguage helps students see how an author is making language choices of different kinds and relate those language choices to what the text is about, how it is structured, and the voice it projects. Learners recognize how to say the same thing in different words and how to recognize differences in register as they work with the same content in different ways.

The key principles that guide the work reported here are a focus on interaction in the context of shared experience of reading a text, using a meaningful metalanguage to read and revisit the text, and building from reading to writing through rich discussion. The metalanguage supports comprehension by providing learners with tools for parsing language into meaningful constituents and recognizing what goes together to make meaning (as seen in the example with did an imitation). It affords opportunities for extended discourse about meaningful curricular issues and supports language production both in whole class and small group settings, giving students resources for engaging with texts and exploring meaning. The teachers and children found this work motivating and 
engaging, as demonstrated by the long attention the second grade class gave to the speech function activity and the enthusiasm with which they participated (at one point the teacher comments, "I've never seen a class so excited about a story"). The activities also support extended oral contributions by L2 learners, contrasting with reports of English learners' silence in content area classroom (e.g., Wedin, 2010).

\section{Conclusion}

In the work presented here, use of SFL metalanguage builds students' capacity to participate in challenging ELA practices in the primary grades. It enables students to abstract from particular language use to generalize about the systems instantiated through that use. It helps them recognize variation and investigate patterns of language in texts and discourse so that they can consider the linguistic choices they have in participating in different tasks and contexts. It supports reading comprehension and writing related to disciplinary content, enabling participation in challenging content-area learning even as students develop language proficiency. Consciousness about language is developed through focused attention on patterns in language, where meaning is foregrounded as students explore how different language choices affect what is meant. This explicit focus on language in the context of interaction and participation in meaningful activity, as has been argued above, provide conditions under which both L2 development and success in school can be achieved.

Viewing language learning in the school years as including the development of new consciousness about language and its patterning in the context of important curricular activities can help educators address the challenges of supporting the development of L2 learners throughout their schooling. These learners' main focus is not on language learning per se but on learning school subjects in the context of simultaneously learning a new language. Use of a meaningful metalanguage offers a means of being explicit about how language presents the knowledge to be developed. In contrast with explicit language teaching in a language class or separately from teaching the curriculum, here the metalanguage is learned in connection with the content and so serves as a pedagogical tool for learning about language that supports learning through language (Halliday, 2004/1980). Embedding the metalanguage in authentic disciplinary work with a focus on what is to be learned extends the notion of content-based language teaching (Stoller, 2004) in the direction of languagebased content teaching, offering new ways of supporting content learning across the school years and school subjects. 
This work has implications for both educational and SLA research. It highlights the need to simultaneously focus on language and content and foreground the development of language resources over accuracy in language use, and suggests that researchers continue to carefully study the interactional moments in which language development is supported. Norris and Ortega (2009) characterized the goal in instructed SLA as understanding what makes a difference in teaching and learning. This article has shown how design-based research can identify ways that metalanguage can support L2 learning in school through explicit focus on disciplinary meanings and how they are construed in language. Following an iterative process of curriculum development in collaboration with teachers, trialing in classrooms, review of processes and outcomes, and revision to respond to challenges or concerns, with close attention to the interactional moments where students and teachers are engaged in talk about language and meaning, reveals both the challenges and affordances of this approach. An important challenge has been to make the metalanguage useful to and usable by teachers in the context of their curricular goals. From a teacher education perspective, a main challenge in the U.S. context is that teachers are seldom prepared to teach grammar in meaningful ways, and often need to be convinced of the value of a focus on language (Locke, 2010). The current lack of knowledge about language on the part of teachers in general has made it necessary that the materials developed support the learning of teachers and children together through enactment of lessons.

Design-based research and the study of microdevelopment is needed to study language development in contexts of use (Larsen-Freeman \& Cameron, 2008), and the measure of development, from this perspective, needs to be participation and content learning, not linguistic accuracy. Larsen-Freeman (2009) suggested that researchers need to employ "socially oriented measures of development" such as "the level of interactivity that a learner evidences. . .or the type of discourse practices in which he or she engages" (p. 587). The SFL meaning-based metalanguage offers opportunities to develop such new measures (see, e.g., Mohan \& Huang, 2002, and the discussion of grammatical metaphor in Norris \& Ortega, 2009), as it helps educators and researchers conceptualize language development in ways that do not focus on errors or lack of errors as markers of development.

In the current context of increasing numbers of L2 learners, teachers need new ways of creating classroom environments that support language learning at the same time that children are engaged in content learning. Recent currents in language learning research offer ways of theorizing this learning as both social and emergent, and the SFL metalanguage provides a meaningful 
framework for engaging learners in the explicit talk about language and meaning that this research shows is likely to be most supportive of academic language development. These understandings about language and learning need to be recruited in research programs that situate the inquiry in the educational contexts in which children are learning in and through an L2 and needing support for language development across the years of schooling. This article has shown how design-based research can contribute to these goals by offering evidence that talk about meaning in the context of classroom activities has the potential to stimulate extended focus on language that raises consciousness about patterns of language and engages learners in talk and writing through which both language and content learning are simultaneously supported.

Revised version accepted 15 September 2012

\section{References}

Anderson, T., \& Shattuck, J. (2012). Design-based research: A decade of progress in education research? Educational Researcher, 41(1), 16-25.

Andringa, S., de Glopper, K., \& Hacquebord, H. (2011). Effect of explicit and implicit instruction on free written response task performance. Language Learning, 61, 868-903.

Berry, R. (2010). Terminology in English language teaching: Nature and use. Bern, Switzerland: Peter Lang.

Brisk, M., \& Zisselsberger, M. (2010). We've let them in on a secret: Using SFL theory to improve the teaching of writing to bilingual learners. In T. Lucas (Ed.), Preparing all teachers to teach English language learners (pp. 111-126). Mahwah, NJ: Lawrence Erlbaum.

Byrnes, H. (2009). Systemic-functional reflections on instructed foreign language acquisition as meaning-making: An introduction. Linguistics and Education, 20, $1-9$.

Christie, F. (2012). Language education throughout the school years: A functional perspective. Language Learning, 62(Supplement 1), 1-247.

Christie, F., \& Derewianka, B. (2008). School discourse: Learning to write across the years of schooling. London: Continuum.

Collins, A., Joseph, D., \& Bielaczyc, K. (2004). Design research: Theoretical and methodological issues. Journal of the Learning Sciences, 13, 15-42.

de Oliveira, L. C. (2008). A linguistic approach in culturally and linguistically diverse classrooms: A focus on teacher education. Linguistics and the Human Sciences, 4, 101-133.

Edelson, D. C. (2002). Design research: What we learn when we engage in design. Journal of the Learning Sciences, 11, 105-121. 
Ellis, N., \& Larsen-Freeman, D. (2006). Language emergence: Implications for applied linguistics - Introduction to the special issue. Applied Linguistics, 27, 558-589.

French, R. (2010). Primary school children learning grammar: Rethinking the possibilities. In T. Locke (Ed.), Beyond the grammar wars: A resource for teachers and students on developing language knowledge in the English/literacy classroom (pp. 206-229). New York: Routledge.

Gebhard, M., Harman, R., \& Seger, W. (2007). Reclaiming recess: Learning the language of persuasion. Language Arts, 84, 419-430.

Gibbons, P. (2006). Bridging discourses in the ESL classroom: Students, teachers and researchers. London: Continuum.

Halliday, M. A. K. (1978). Language as social semiotic. London: Edward Arnold.

Halliday, M. A. K. (1993). Towards a language-based theory of learning. Linguistics and Education, 5, 93-116.

Halliday, M. A. K. (2004/1980). Three aspects of children's language development: Learning language, learning through language, learning about language. In J. Webster (Ed.), The language of early childhood (Vol. 4, pp. 308-326). London: Continuum.

Halliday, M. A. K. (2007/1978). Is learning a second language like learning a first language all over again? In J. Webster (Ed.), Language and education (Vol. 9, pp. 174-193). London: Continuum.

Halliday, M. A. K., \& Matthiessen, C. M. I. M. (2004). An introduction to functional grammar (3rd ed.). London: Arnold.

Hasan, R., \& Perrett, G. (1994). Learning to function with the other tongue: A systemic functional perspective on second language teaching. In T. Odlin (Ed.), Perspectives on pedagogical grammar (pp. 179-226). Cambridge, UK: Cambridge University Press.

Larsen-Freeman, D. (2009). Adjusting expectations: The study of complexity, accuracy, and fluency in second language acquisition. Applied Linguistics, 30, 579-589.

Larsen-Freeman, D., \& Cameron, L. (2008). Research methodology on language development from a complex systems perspective. Modern Language Journal, 92, 200-213.

Locke, T. (Ed.). (2010). Beyond the grammar wars: A resource for teachers and students on developing language knowledge in the English/literacy classroom. New York: Routledge.

Martin, J. R. (1993). Genre and literacy-Modeling context in educational linguistics. Annual Review of Applied Linguistics, 13, 141-172.

Martin, J. R., \& Rose, D. (2003). Working with discourse. London: Continuum.

Matthiessen, C. M. I. M. (2009). Meaning in the making: Meaning potential emerging from acts of meaning. Language Learning, 59(Supplement 1), 206-229.

Mohan, B., \& Huang, J. (2002). Assessing the integration of language and content in a Mandarin as a foreign language classroom. Linguistics and Education, 13, 407-435. 
Myhill, D. (2003). Principled understanding? Teaching the active and passive voice. Language and Education, 17, 355-370.

Norris, J. M., \& Ortega, L. (2009). Towards an organic approach to investigating CAF in instructed SLA: The case of complexity. Applied Linguistics, 30, 555-578.

Quinn, M. (2004). Talking with Jess: Looking at how metalanguage assisted explanation writing in the middle years. Australian Journal of Language and Literacy, 27, 245-261.

Schleppegrell, M. J. (2004). The language of schooling: A functional linguistics perspective. Mahwah, NJ: Lawrence Erlbaum.

Schleppegrell, M. J. (2011). Supporting disciplinary learning through language analysis: Developing historical literacy. In F. Christie \& K. Maton (Eds.), Disciplinarity: Functional linguistic and sociological perspectives (pp. 197-216). London: Continuum.

Schleppegrell, M. J. (2012). Academic language in teaching and learning: Introduction to the special issue. Elementary School Journal, 112, 409-418.

Simard, D., \& Jean, G. (2011). An exploration of L2 teachers' use of pedagogical interventions devised to draw L2 learners' attention to form. Language Learning, 61, 759-785.

Spada, N., \& Tomita, Y. (2010). Interactions between type of instruction and type of language feature: A meta-analysis. Language Learning, 60, 263-308.

Stoller, F. (2004). Content-based instruction: Perspectives on curriculum planning. Annual Review of Applied Linguistics, 24, 261-283.

Svalberg, A. (2007). Language awareness and language learning. Language Teaching, 40, 287-308.

Watson-Gegeo, K., \& Nielsen, S. (2003). Language socialization in SLA. In C. Doughty \& M. Long (Eds.), Handbook of second language acquisition (pp. 155177). Malden, MA: Wiley-Blackwell.

Wedin, A. (2010). A restricted curriculum for second language learners-A self-fulfilling teacher strategy? Language and Education, 24, 171-183.

Williams, G. (2004). Ontogenesis and grammatics: Functions of metalanguage in pedagogical discourse. In G. Williams \& A. Lukin (Eds.), The development of language: Functional perspectives on species and individuals (pp. 241-267). London: Continuum.

Young, R. F. (2008). Discursive practice in language learning and teaching. Language Learning, 58(Supplement 2), 1-267.

Zuengler, J., \& Miller, E. R. (2006). Cognitive and sociocultural perspectives: Two parallel SLA worlds? TESOL Quarterly, 40, 35-58. 